\title{
UNDERSTANDING OF THE BENEFITS AND VALUE OF GOODS AND ITS EFFECT ON STUDENT CREATIVITY IN UTILIZING USED GOODS: MINDSET OF STUDENT ENTERPRENEUR
}

\author{
Dicki Hartanto $^{1)}$, Yulisyah Fitriana ${ }^{2)}$, Sri Yuliani ${ }^{3)}$ \\ E-mail: dicki.hartanto@uin-suska.ac.id \\ 1)2) Economic Education, FTK, Universitas Islam Negeri Sultan Syarif Kasim Riau \\ ${ }^{3)}$ FKIP, Universitas Islam Riau
}

\begin{abstract}
Penelitian ini membahas tentang pengaruh manfaat materi dan nilai barang terhadap kreativitas siswa dalam memanfaatkan barang bekas. Penelitian ini bertujuan untuk mengetahui seberapa besar pengaruh nilai dan manfaat materi terhadap kreativitas siswa dalam memanfaatkan barang bekas di SMAN 1 Salo Kabupaten Kampar. Penelitian ini dilakukan di SMA Negeri Salo 1 Kabupaten Kampar dengan subyek 57 siswa. Penelitian ini dilaksanakan pada tanggal 19 Juli - 9 September 2013, dengan teknik pengumpulan data melalui tes, angket (angket) dan dokumentasi, sedangkan objek penelitian ini adalah manfaat materi dan nilai suatu barang, serta kreativitas siswa dalam memanfaatkan barang bekas. . Berdasarkan hasil analisis data dapat disimpulkan bahwa manfaat materi dan nilai suatu barang mempunyai pengaruh yang signifikan terhadap kreativitas siswa dalam memanfaatkan barang bekas. Hal ini terlihat dari $r$ hitung Product Moment yang lebih besar dari $r$ tabel baik dari taraf signifikan $5 \%$ maupun $1 \%(0,250<0,450>0,325)$. Terkait dengan pola pikir kewirausahaan dalam upaya mendorong wirausaha yang berasal dari generasi muda, kurikulum pendidikan kita harus menanamkan potensi wirausaha pada diri siswa.
\end{abstract}

Kata Kunci: Kreativitas Mahasiswa, Pemahaman Penggunaan Materi dan Nilai, Wirausaha Pola pikir

\section{INTRODUCTION}

Education is a conscious endeavor and aims to develop human qualities. As an activity that is aware of its goals, its implementation is in a continuous process in every type and level of education (Djamarah, 2005). Education can also develop the creativity of students and teachers. Creativity is the result of learning in cognitive skills, so that being creative can be learned through the teaching and learning process (Daryanto, 2010). The implication is that creative abilities can be increased through education (Munandar, 2009).

Creativity is a process that demands balance and application of the three essential aspects of analytical, creative and practical intelligence, several aspects which when used in a combination and balance will give birth to the intelligence of success (Riyanto, 2009). Meanwhile, student creativity is the ability of students to create or make something useful (Munandar, 2009).

Creative students are able to create or make used goods into useful and useful items and can increase income. Creativity is very important for humans in everyday life. Creativity itself is not just luck for those who have it, but it takes hard work to achieve it. For students who are creative, failure is a saving factor until they succeed, because they use all the knowledge they have to achieve what they want. To achieve this desire, an understanding of the material 
benefits and value of an item is needed.

Meanwhile, understanding of learning material is very important in a learning process. Understanding this, students are required to understand or understand what is being done, to know what is being communicated and to be able to take advantage of its contents without having to connect with other things.

Instructional materials are knowledge, skills, and attitudes that students must learn in order to achieve predetermined competency standards (Mudasir, 2012). The material benefits and value of a student's item are required to be able to know and be able to take advantage of and be able to predict the use value of an item, especially ready-to-use or used goods.

The material benefits and use value of an item are very important and make students more creative and more able to use the items around them to become items of sale value, so the researchers assume that Salo 1 Public Senior High School students must be even more creative in using them. and be more observant of the use value of these recycled items.

Based on the preliminary study conducted by the researcher, the understanding of the material benefits and value of an item at SMAN 1 Salo is good, but students are not creative enough in using used goods. This can be seen based on the following symptoms:

1. There are still students who lack creative ideas

2. Students still lack curiosity about new things

3. There are still students who are not enthusiastic about taking economics lessons on the benefits and value of an item, indicated by the fact that there are still students who are sleepy while taking economics lessons.

4. There are still students who do not have the courage to express their opinion

5. There are still students who are less creative in using used goods, indicated by the fact that there are still students who have not used used goods

\section{RESEARCH METHOD}

This research was conducted on July 19 to September 9, 2013 at Senior High School 1 Salo class X, Salo District, Kampar Regency.

The population in this study were 132 students of SMAN 1 Salo. From this population, the authors took a sample of 57 students. This sampling technique uses the Slovin formula.

Data collection techniques in this study used:

- Test, the researcher gave a test in the form of multiple choice questions.

- Questionnaires or questionnaires, namely by distributing questionnaires to students.

- Documentation, data in the form of school conditions, teacher conditions, teacher conditions, student conditions and the curriculum of Public Senior High School 1 Salo.

Regression is used to determine how high the value of the dependent variable is when the value of the independent variable is manipulated. In general, the simple regression equation (Sugiyono, 2012) can be formulated as follows:

$$
\mathrm{Y}=\mathrm{a}+\mathrm{bX}
$$

\section{Remarks :}

$\mathrm{Y} \quad=$ predicted value

a $\quad=$ constant or when the value of $\mathrm{X}=0$

$\mathrm{b} \quad=$ regression coefficient

$\mathrm{X}=$ independent variable value

Analysis for hypothesis testing is carried out further by testing the value of $r$ and by comparing it with $\mathrm{r}_{-} \mathrm{t}$ (table) to determine the significant level of testing the hypothesis, namely if the value of $r_{-} 0$ (observation) is greater than $\mathrm{r} \_\mathrm{t}$ (table) then $\mathrm{H} \_\mathrm{a}$ is accepted and $\mathrm{H} \_0$ is rejected and vice versa if the value $r_{-} 0$ (observation) is smaller than $\mathrm{r} \_\mathrm{t}$ (table) then $\mathrm{H} \_\mathrm{a}$ is rejected and H_0 is accepted.

Contribution of the influence of variable $\mathrm{X}$ (Economic Learning Material Benefits and Value of an Item) and variable Y (Student Creativity Utilizing Used Goods).

Calculating the Contribution of the Influence of the variable X (Economic Learning Material Benefits and Value of an Item) and Y 
variable (Student Creativity Utilizing Used Goods can use the formula:

$$
\mathrm{KD}=R^{2} \times 100 \%
$$

The analysis was carried out using the assistance of the SPSS 19.00 program.

\section{FINDINGS}

Data on student understanding of the benefits and value of an item are measured based on the minimum completeness criteria (KKM) as follows:

- A value greater than or equal to $(\leq 70)$ is categorized as complete.

- A value less than 70 is categorized as incomplete.

Grading can determine students' understanding of the benefits and value of an item at SMAN 1 Salo. Every correct answer is given a point (1), and every wrong answer is given a zero point $(0)$.

From the results of processed data about students' understanding of the benefits and value of an item obtained, it is known that the number of students who have been categorized as complete is 57 students. Meanwhile, the highest score for understanding the benefits of material and the value of an item was 93.33, while the lowest score for students was 73.33, while the average was $\mathbf{8 2 . 4 6}$.

Table 1

\section{Objective Test Assessment Criteria}

\begin{tabular}{lcr}
\hline Score & Alphabet & Predicate \\
\hline 80 above & A & Very Good \\
$66-79$ & B & Good \\
$56-65$ & C & Enough \\
$46-55$ & D & Less \\
45 below & E & Failed \\
\hline
\end{tabular}

Based on the average number of values, namely 82.46, seen from the assessment criteria categorized students' understanding of the material benefits and the value of an item is Very Good.

Presentation of data about students' creativity in utilizing used goods using a questionnaire. Presentation of data based on a questionnaire given to class $\mathrm{X}$ students at SMAN 1 Salo with 57 students as respondents.
The score is to determine the creativity of students in utilizing used goods at SMAN 1 Salo, so each alternative frequency of answers is multiplied by each answer. The percentage figure is obtained using the following formula:

$$
\begin{array}{r}
\mathrm{p}=\frac{F}{N} \times 100 \% \\
\mathrm{p}=\frac{4211}{5130} \times 100 \% \\
\mathrm{p}=\mathbf{8 2 . 0 8 \%}
\end{array}
$$

Student creativity in utilizing used goods at SMAN 1 Salo is $82.08 \%$ in the "Very Good" category.

The hypotheses tested in this study are:

Ha: There is an effect of understanding the benefits and value of an item on student creativity using used goods

H0: There is no effect of understanding the benefits and value of an item on student creativity in utilizing used goods

The value of the coefficient of understanding the useful material and the value of an item on students' creativity in utilizing used goods at SMAN 1 Salo, Kampar Regency is 0.450 . From the results of this analysis, it can be seen:

$$
\begin{aligned}
& \text { Df }=\mathrm{N}-\mathrm{nr} \\
& \text { Df }=57-2 \\
& \text { Df }=55
\end{aligned}
$$

rt (table) at a significant level of $5 \%=0.250$ rt (table) at a significant level of $1 \%=0.325$ ro (count) $=0.450$ when compared with rt (table) at a significant level of $5 \%(0.450>0.250)$ this means that Ha is accepted, Ho is rejected.

ro $($ count $)=0.450$ when compared with rt (table) at a significant level of $1 \%(0.450>0.325)$ this means that Ha is accepted, Ho is rejected.

Based on the description above, it is concluded that there is a significant influence between understanding the benefits and value of an item and students' creativity in utilizing used goods at SMAN 1 Salo, Kampar Regency.

Contribution of the influence of the Material Benefits and Value of an Item on Student Creativity in Utilizing Used Goods at SMAN 1 Salo, then from the results of the SPSS 19.00 analysis it is said that the coefficient of determination $r$ square is 0.203 . So that the 
contribution of the influence of understanding the benefits and value of an item on the creativity of students using used goods is $20.3 \%$ and the remaining $79.7 \%$ is determined by other factors.

\section{DISCUSSION}

The results of the assessment related to students' understanding of the benefits and value of an item with a value of 82.46 are included in the Very Good category. These results indicate that students' understanding of the benefits and value of an item in economic subjects is above average.

Beetlestone (2011) explains that understanding is not just a sense of knowing, but also is able to make students think more creatively. So that students will easily understand the lessons they are learning, students who are said to understand if they have understood.

This result is in accordance with the research conducted by Rusydi Noviana (2016) which concluded that the creative economy has a significant effect on the creativity of the Cut Meutia Dance Studio adolescents in Lhokseumawe City with a determination coefficient value of 0.306 , this shows that the ability of the independent variable (creative economy) can explain the effect. the dependent variable (teenager creativity) was $30.6 \%$, the remaining $57.2 \%$ was influenced by other variables not included in this research model.

Another study conducted by Sulistri (2013) entitled The Effect of the Understanding of the Trading Goods Inventory Recording System on Student Learning Outcomes Calculating the Inventory Price of Class XII Students at Tri Bhakti High School Pekanbaru resulted in the conclusion that there was an effect of understanding the trading system recording system on student learning outcomes calculating earnings. supplies of class XII students of the Department of Social Studies SMA Tri Bhakti Pekanbaru.

Because most of our education gives birth to workers, our graduates are more interested in civil servants, office work, even though if we want to advance the country, one of them is through the business world and also does not see entrepreneurial activities as having a lower stratum than being government employees or private employees. Because, if a serious business has been cultivated from a young age, and developed with all the available potential, entrepreneurship will make someone who is respected and is also able to provide employment facilities for others. Therefore it is important for teachers to encourage an entrepreneurial mindset among students.

\section{IMPLICATION}

Based on it can be concluded that students' understanding of the material benefits and value of an item is quite high, based on the average assessment criteria, namely $82.46 \%$ categorized as very good. Meanwhile, students' creativity in the use of used goods was categorized as very good, namely $82.08 \%$. Contribution of the effect of understanding the benefits and value of an item on the creativity of students using used goods is categorized as good enough is $20.3 \%$ and the remaining $79.7 \%$ is determined by other factors.

Here are some things the author needs to recommend,

1) Students should be active in the teaching and learning process so that it is easy to understand the material presented by the teacher.

2) Students should be even more creative in utilizing used goods around their environment.

3) The teacher can apply learning patterns that are able to make students not easily bored in learning so that the learning material is easily understood by students

4) The teacher should also be able to change the mindset of students so that they have entrepreneurial skills from an early age in school.

The author realizes that in this research it is inseparable from weaknesses and mistakes, for the sake of the perfection of this thesis it is hoped that the criticism and suggestions are constructive. The author hopes that this thesis is useful for all of us. 


\section{BIBLIOGRAPHY}

Al-Qur'an and its Translation

Alamendah. 2013. Pengertian Dan Proses Daur Ulang, http://alamendah. wordpress.com/2011/01/22/pengertia n-dan-proses-daur-ulang/ (diakses 27 Januari 2013, pukul 23.19 wib)

Anas Sudijono, 2011, Pengantar Evaluasi Pendidikan, Jakarta : Rajawali Pres

Anas Sudijono, 2009, Pengantar Statistik Pendidikan, Jakarta : Rajawali Pers

Djaali, 2009, Psikologi Pendidikan, Jakarta : Bumi Aksara

Daryanto, 2010, Belajar dan Mengajar, Bandung: Yrama Widya

E. Mulyasa, 2005, Kurikulum Berbasis Kompetensi : Konsep, Karakteristik, dan Implementasi, Bandung : PT. Remaja Rosdakarya

Emilia Setyoningtyas. 2012. Kamus Trendy Bahasa Indonesia, Surabaya; Apollo

Endang Danial, 1994, Penuntun Belajar Ekonomi 1, Bandung: Ganeca Exact

Florence Beetlestone, 2011, Creative Learning : Strategi Pembelajaran untuk Melesatkan Kreativitas Siswa, Bandung : Nusa Media

Hari Suderadjat. 2004, Implementasi Kurikulum Berbasis Kompetensi (KBK) Pembaharuan Pendidikan dalam Undang-undang Sisdiknas 2003, Bandung; CV Cipta Cekas Grafika

Hariyanto. 2012. Kreativitas Guru Dalam Pembelajaran Ekonomi Sekolah Menengah Atas Negeri 1 Kampar Kiri Hulu Kabupaten Kampar, Skripsi, Pekanbaru : Fakultas Tarbiyah dan Keguruan UIN Suska Riau, 2012.
Hartono, 2010, Analisis Data Instrumen, Bandung : Zanafa Publishing bekerja sama dengan Nusa Media Bandung

Husein Umar, 2004, Metode Riset Ilmu Administrasi, Jakarta: PT. Gramedia Pustaka Utama

Mardiyatmo, 2010, Economics 1 Senior High School Year 1, Jakarta : Yudistira

Mita Sirait, 2009, Sulap Sampah Plastik Keras Jadi Jutaan Rupiah, (Yogyakarta: Bfirst (PT Bentang Pustaka)

M. Iqbal Hasan, 2009, Pokok-pokok materi Statistik 1, Jakarta : PT. Bumi Aksara

Mr. Windu, Manfaat Dan Niali Suatu Barang,http://ips-mrwindu.blogspot. com/2012/01/-manfaat-dan-nilai-suatubarang.html?m=1, tahun 2012 (diakses 03 April 2013)

Mudasir, 2012, Desain Pembelajaran, Air Molek Indragiri Hulu : STAI Nurul Falah Press.

Ngalim Purwanto, 2004, Psikologi Pendidikan, Bandung: PT. Remaja Rosda Karya

Noviana, Rusyidi. 2016. Pengaruh Penerapan Ekonomi Kreatif Terhadap Kreativitas Remaja Di Kota Lhokseumawe (Studi Kasus Pada Seni Tari Sanggar Cut Meutia) dalam JURNAL VISIONER \& STRATEGIS Volume 5, Nomor 1, Maret 2016 ISSN : 2338-2864 p. 51-59

Nurasia. 2011. Pengaruh Materi Kreativitas pada Ilmu Pengetahuan Sosial Terpadu Terhadap Kreativitas Siswa Kelas VIII di MTs Negeri Padang Mutung, Skripsi, Pekanbaru : Fakultas Tarbiyah dan Keguruan UIN Suska Riau, 2011.

Oemar Hamalik, 2010, Psikologi Belajar Mengajar, Bandung : Sinar Baru Algesindo 
Tohirin, 2005, Psikologi Pembelajaran Penddidikan Agama Islam, Jakarta : PT. RajaGrafindo Persada

Usman, M. Basuki Aswawir, 2002, Media Pembelajaran, Padang : Ciputat perss

Utami Munandar, 2009, Pengembangan Kreatifitas Anak Berbakat, Jakarta: PT. Rineka Cipta

Riduwan, 2011, Skala Pengukuran VariabelVariabel Penelitian, Bandung : Alfabeta

Slameto, 2010, Belajar dan Faktor-faktor yang mempengaruhinya, Jakarta : Rineka Cipta

Sugiyono, 2012, Metode Penelitian Pendidikan Pendekatan Kuantitatif Kualitatif dan $R \& D$, Bandung : Alfabeta

Sulistri, 2013. Pengaruh Pemahaman Sistem Pencatatan Persediaan Barang Dagang Terhadap Hasil Belajar Siswa Menghitung Harga Perolehan Persediaan Siswa Kelas XII Di SMA Tri Bhakti Pekanbaru, Skripsi, Pekanbaru : Fakultas Tarbitah dan Keguruan UIN Suska Riau, 2013.

Suparmin, Putri Hapsari, Kasafa Putri, Pegangan Guru Buku Kerja Siswa SMA/MA Ekonomi X Smt Gasal. (Surakarta: Mediatama, Edisi VI)

Suryana Yuyus dan Bayu Kartib, 2010, Kewirausahaan;pendekatan karakteristik wirausahawan sukses, Jakarta; Kencana Media Group.

Syaiful Bahri Djamarah, 2005, Guru dan Anak Didik dalam Interaksi Edukatif, Jakarta : PT. Rineka Cipta, cet. 3

Wina Sanjaya, 2010, Kurikulum dan Pembelajaran Teori dan Praktik Pengembangan KTSP, Jakarta: Kencana
Yatim Riyanto. 2009. Paradigma Baru Pembelajaran Sebagai Referensi Bagi Pendidik Dalam Implementasi Pembelajaran yang Efektif dan Berkualitas,Jakarta; Kencana Prenada Media Group 